\title{
Putting Knowledge to Work: Outcome Performance of the UF/IFAS Welfare to Work Initiative
}

\author{
Elizabeth B. Bolton, Professor \\ Community Development \\ Department of Family, Youth and Community Sciences
}

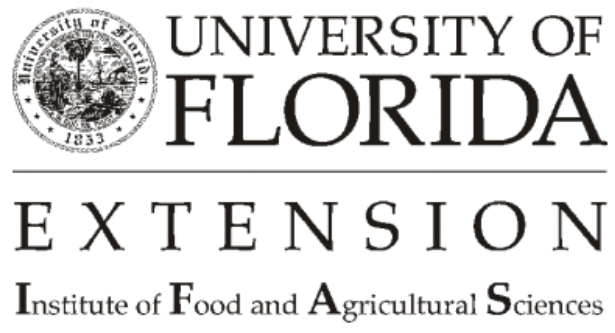


The outcomes of the UF/IFAS Welfare to Work (WtW) Initiative are measured in terms of jobs obtained by the targeted client group and the hourly wages earned in these jobs. In order to achieve the outcome of participants obtaining jobs, they must first be exposed to some treatment, in this case an educational program delivered by the WtW project. The UF/IFAS WtW courses were developed specifically for the WtW client group. While a cause and effect outcome cannot be claimed, the outcomes of the WtW project are directly related to the curriculum and the instruction provided. The outcomes shown below are from the locations implementing the project. The site supervisors responsible for the implementation of the project and supervision of the WtW instructor are as follows:

Bay County - Majorie Moore, County Extension Director Madison County - Jim Fletcher, County Extension Director Suwannee County - Meredith Taylor, County Extension Director and Bob Hochmuth, Suwannee Valley Regional Educational Center Leon County - Betty Miller, Extension Agent III Hillsborough County - Mary Chernesky, County Extension Director Pinellas County - Gary Pleiss, Courtesy Extension Agent I Lee County - Susan Hedge, County Extension Director Palm Beach County - Audrey Norman, Courtesy Extension Agent I Broward County - Mary Peters, County Extension Director

Columbia County operates the WtW program through the Florida Crown Workforce Board without affiliation of the Columbia County Extension Office. Supervision is from the WtW office on campus.

Shown below are the outcomes based on the total number of locations currently or previously involved in the implementation of the WtW Initiative. A data base of each client enrolled in and completing one or more of the educational courses is maintained and the information provided below is compiled from this data base of clients.

\begin{tabular}{|c|c|}
\hline Total Enrollments & Total Completions \\
\hline 614 & 514 \\
\hline
\end{tabular}

The above table shows the outcomes associated with the UF/IFAS WtW courses as of May 11, 2001. Column one shows enrollment by course with a Total Course Enrollment being 614. It should be noted that a participant may enroll in more than one course. This is to be expected because participants are encouraged to take more than one course as described above in the Learning Continuum Model. 
Figure 1.

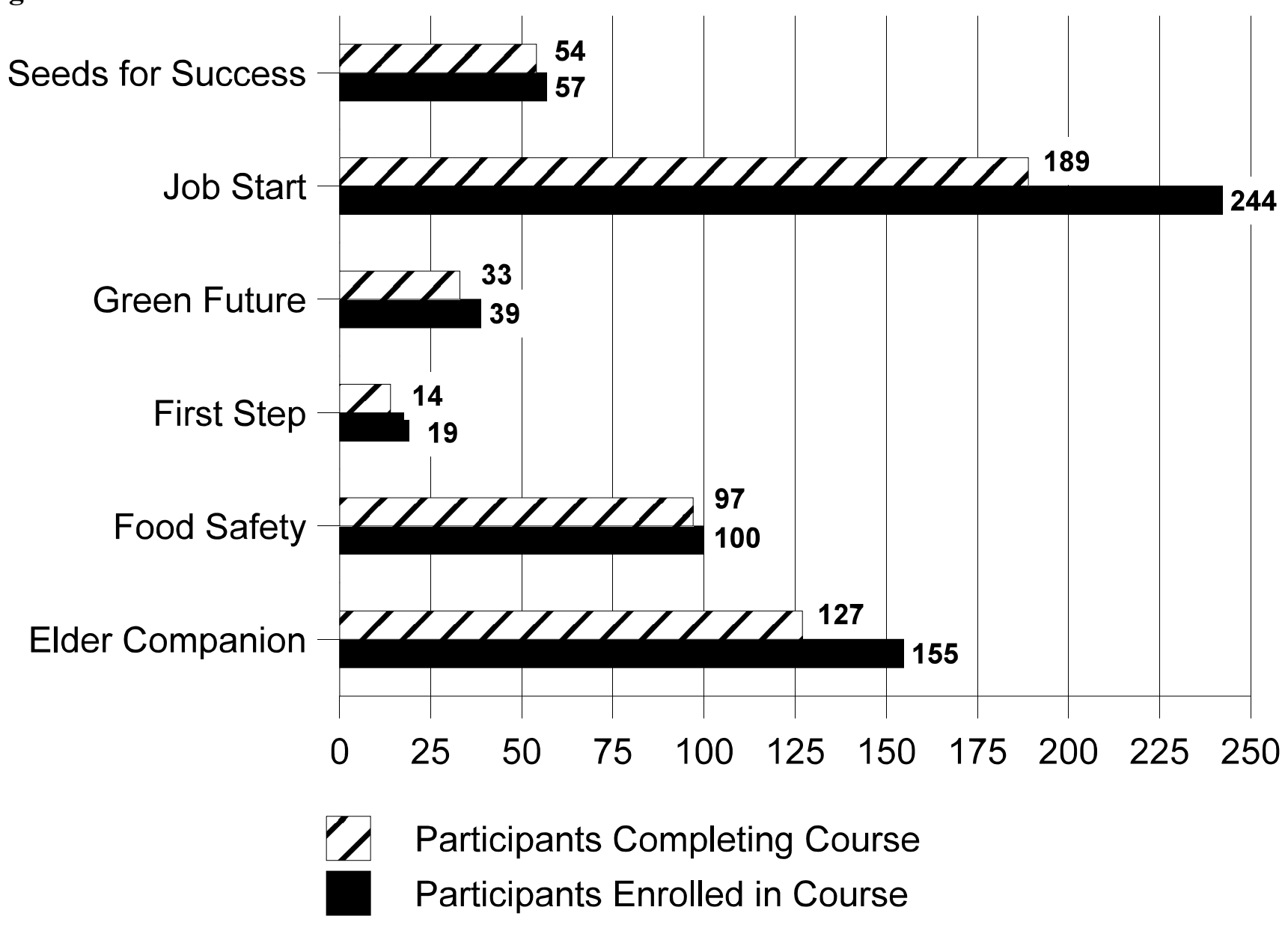

Figure 1. Participant enrollment and completion by course is drawn in a histogram for each WtW course with number of participants enrolling in and completing a given course. Not all participants enrolling in a course completed it, thus the difference shown in the bars in Figure 1. The courses having the largest enrollments and completions were JobStart $(\mathrm{N}=244)$, followed by Elder Companion $(\mathrm{N}=155)$. 
Figure 2.

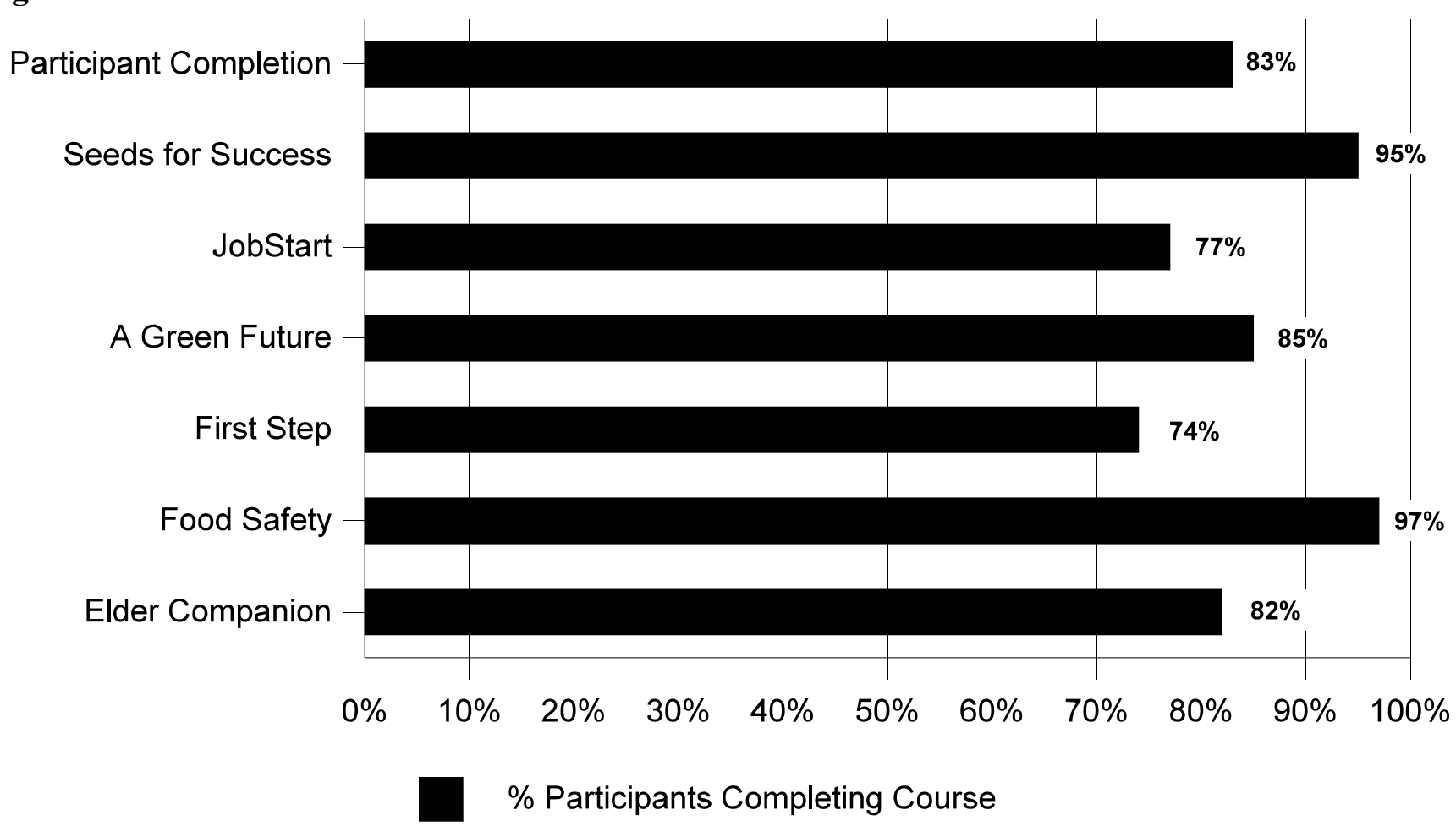

Figure 2. Participant completions as a percent of enrollment by course is shown in Figure 2 with Food Safety and Seeds for Success leading with 97 percent and 95 percent respectively. Comparing Figure 1 and Figure 2, Seeds for Success had a total of 57 enrollments with 95 percent completing the course while Food Safety had 100 enrollments with 97 percent completing the course. 
Figure 3.

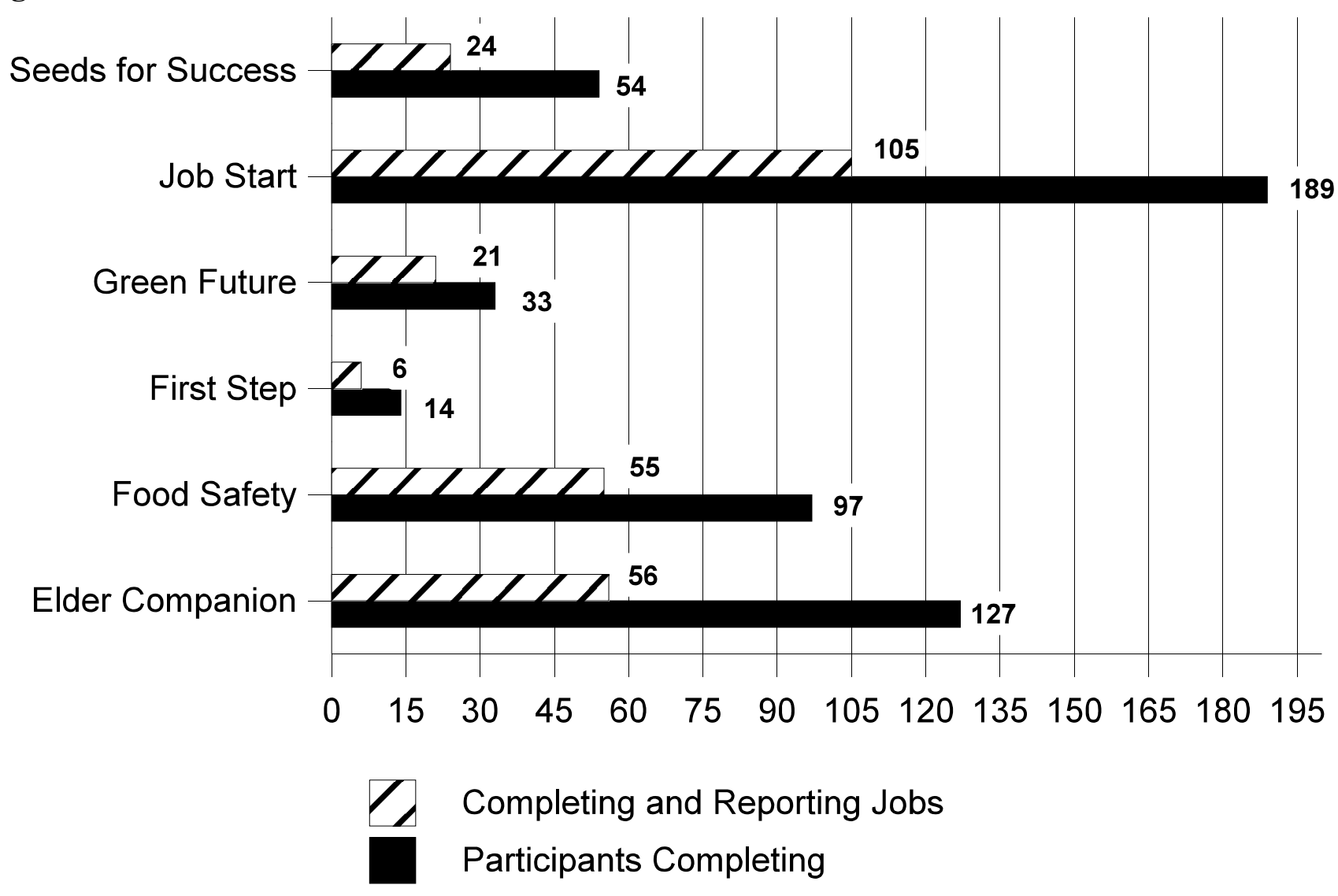

Figure 3. Participant completion and employment by course is shown in Figure 3. JobStart has the largest number of client completions $(n=189)$ and jobs held that were related to the training $(n=105)$ Food Safety has 97 completing the course with 55 reporting jobs. The first task is to recruit WtW clients for training and then to retain them until they have finished at least one complete course. However, just completing a course does not mean that the participant goes immediately to work in unsubsidized employment. Thus the number of participants completing a course is always more than the number working in a particular context represented by the job. However the desired outcome is to have course completions match jobs held as near as possible. 


\section{Figure 4.}

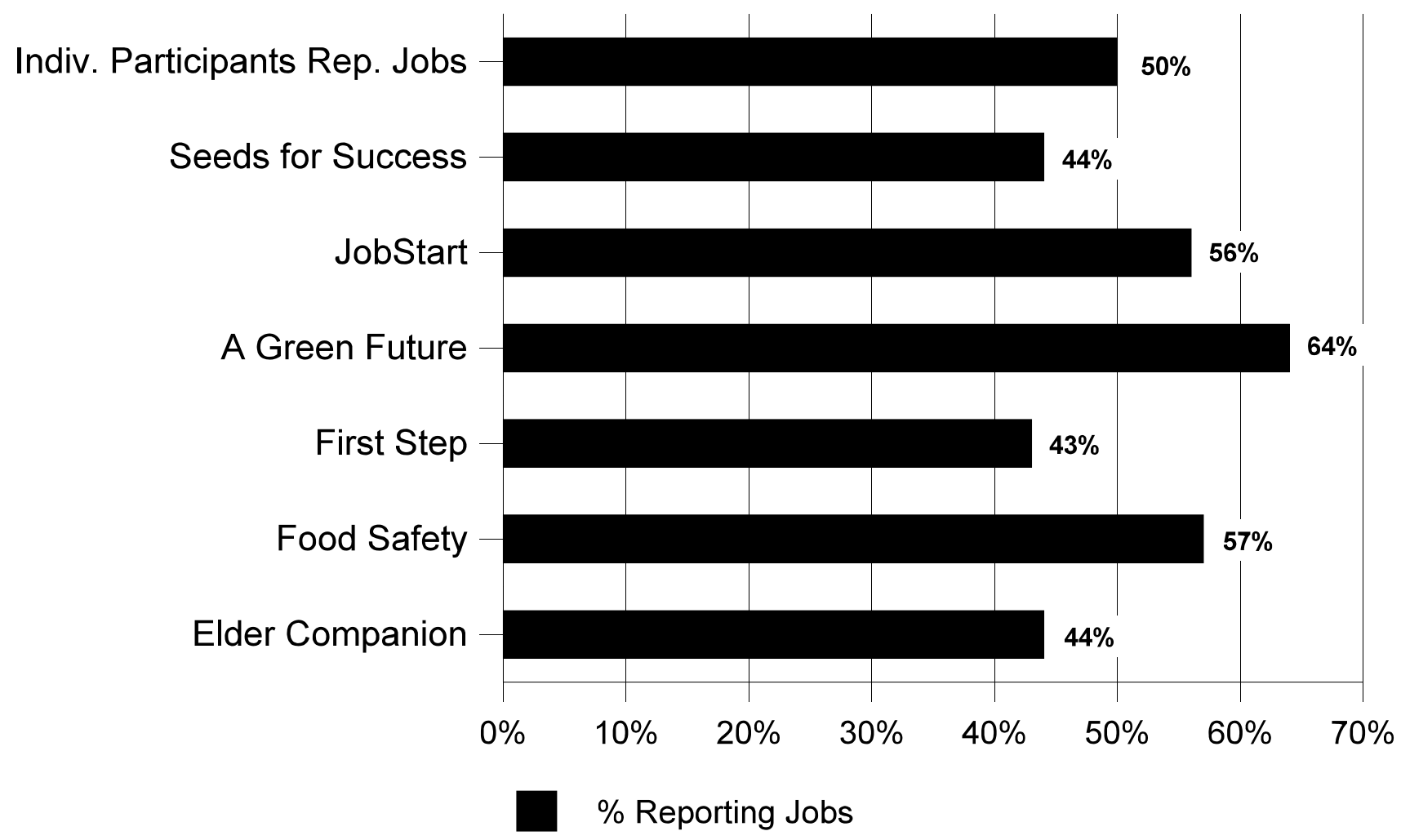

Figure 4. The percent of participant completions reporting jobs is shown in Figure 4. Fifty percent of the participants completing one or more courses reported having a job. Green Futures shows the largest percent of participants reporting jobs, 64 percent, although Green Futures has the second fewest number of course completions, $n=33$, as shown in Figure 3. The high percentage of Food Safety participants reporting jobs, 57 percent, may be due to the fact that the Food Safety training now includes the Florida mandated Food Handler component which is also taught by the UF/IFAS WtW instructors after they become certified to teach the Food Handler course. 
Figure 5.

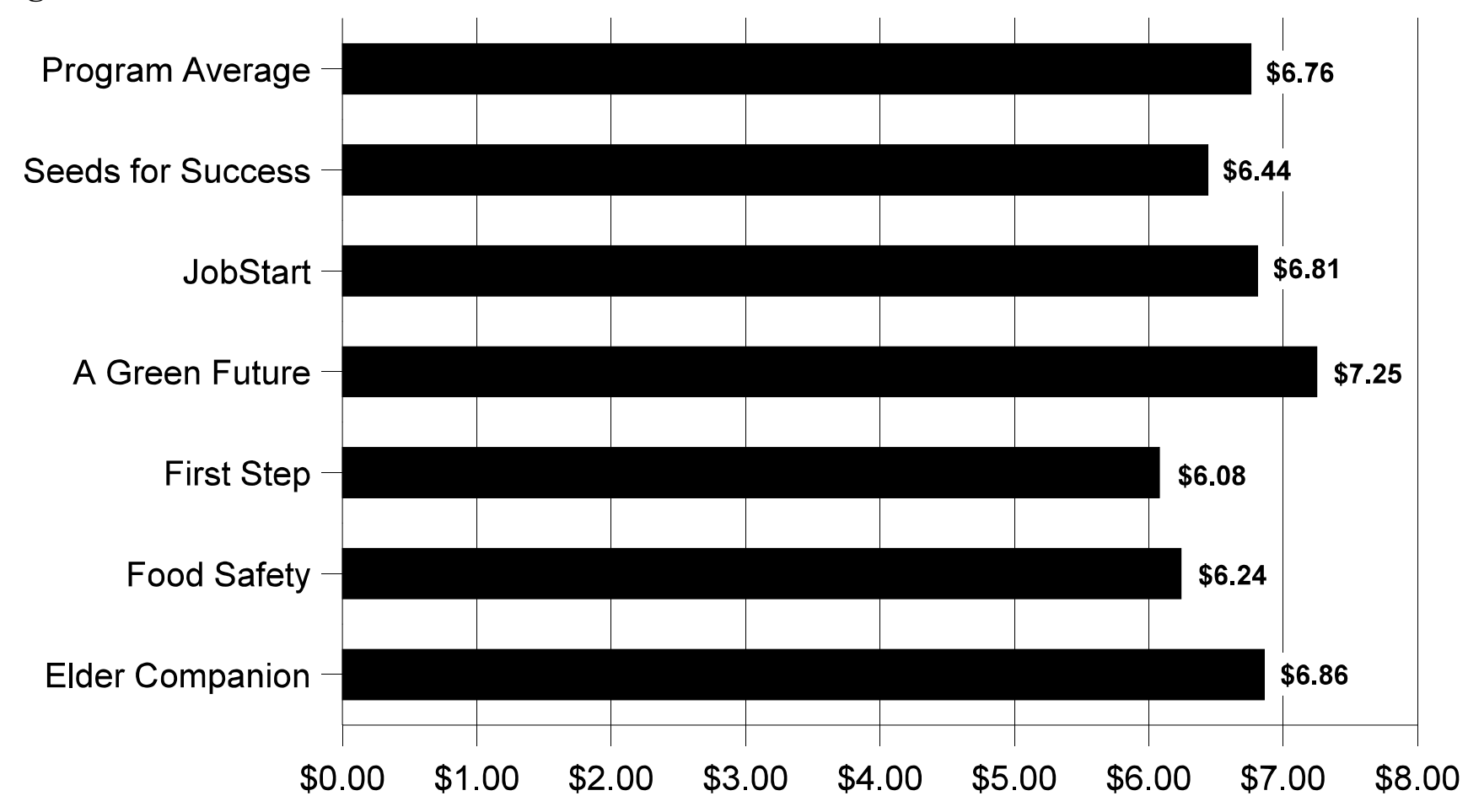

Average Hourly Wage of Participants Completing Courses

Figure 5. Shown above in Figure 5 is the average hourly wage of participants completing WtW courses. All courses show averages above the minimum wage with the program average at $\$ 6.76$ per hour. The highest hourly wage is reported by graduates of the Green Futures course with $\$ 7.50$ per hour. The number of Green Futures completions is small $(\mathrm{n}=25)$ because the horticulture courses are taught only in three locations, Panama City, Live Oak/Lake City and Madison. It should be noted that FastTrac First Step is an entrepreneurship education course for limited income persons and does not necessarily prepare them for employment. In this case however, participants who took these courses did not always start their own business and some went to work for an employer instead. 


\section{Figure 6.}

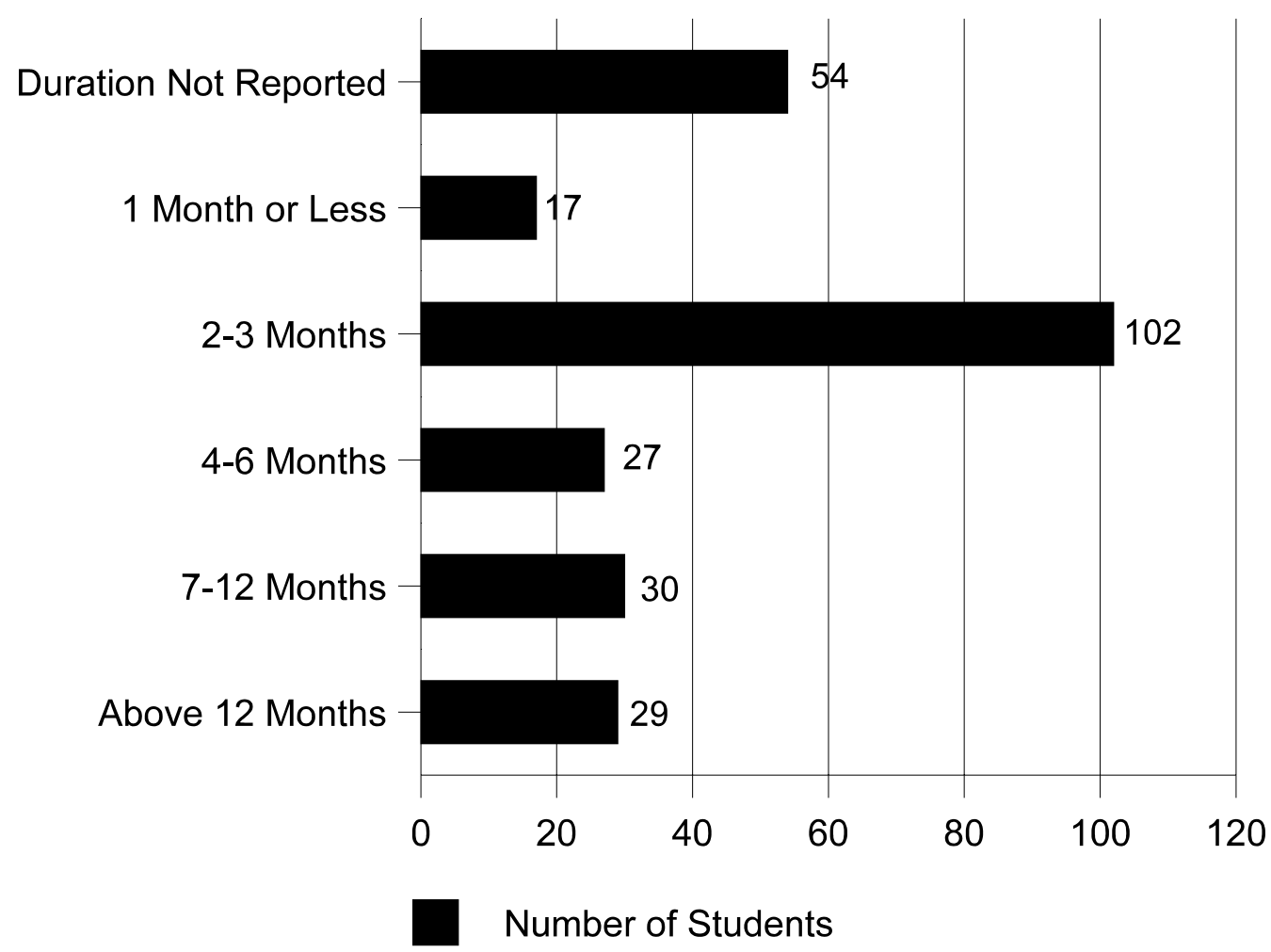

Figure 6. UF/IFAS WTW employed participants: duration of employment since training shows the duration of placement in unsubsidized jobs reported by participants completing one or more of the WtW courses is shown in Figure 6. Each of the 259 persons is reported in only one of the categories indicating length of time employed since completing one or more of the WtW courses. Of those holding jobs, 54 did not report a placement date. Seventeen reported working for one month or less with one hundred two reporting work for two to three months; 27 reporting work for 4 to 6 months. The highest number working is in the 7 to 12 month range with 30 reporting and 29 report working for more than 12 months. The UF/IFAS on-site instructors work with the participants to help them find jobs. The instructors also work with the One Stop job counselor when this is possible. Thus the instructors are not only recruiting and teaching, they also help participants find and retain jobs. 
Figure 7.

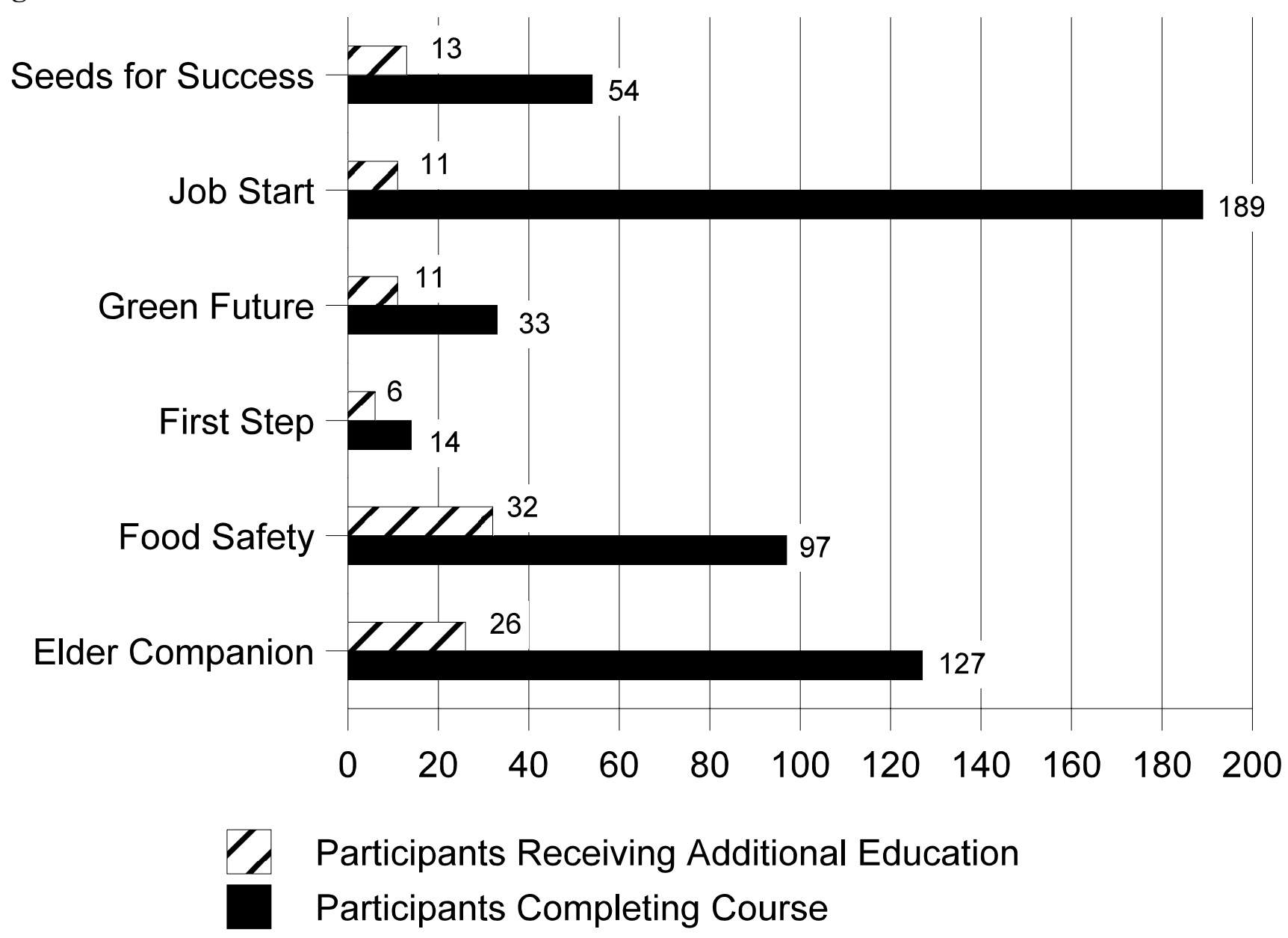

Figure 7. Additional education refers to course completers who enrolled in GED classes or vocational education courses such as certified nursing assistant. The majority of the participants choosing to receive additional education did not get a job immediately upon completion and most of the additional education refers to the General Equivalency Diploma. It should be noted that assisting WtW participants with obtaining additional education is not part of the UF/IFAS contract. However, contacts with the participants indicate that many times additional education is a step toward a higher paying job than might otherwise be available or it may be needed in order to get the first job as in the case of a GED. Although the numbers are small, additional education is reported because here because it is consistent with the mission and purpose of the University of Florida and of Cooperative Extension. 


\section{Figure 8.}

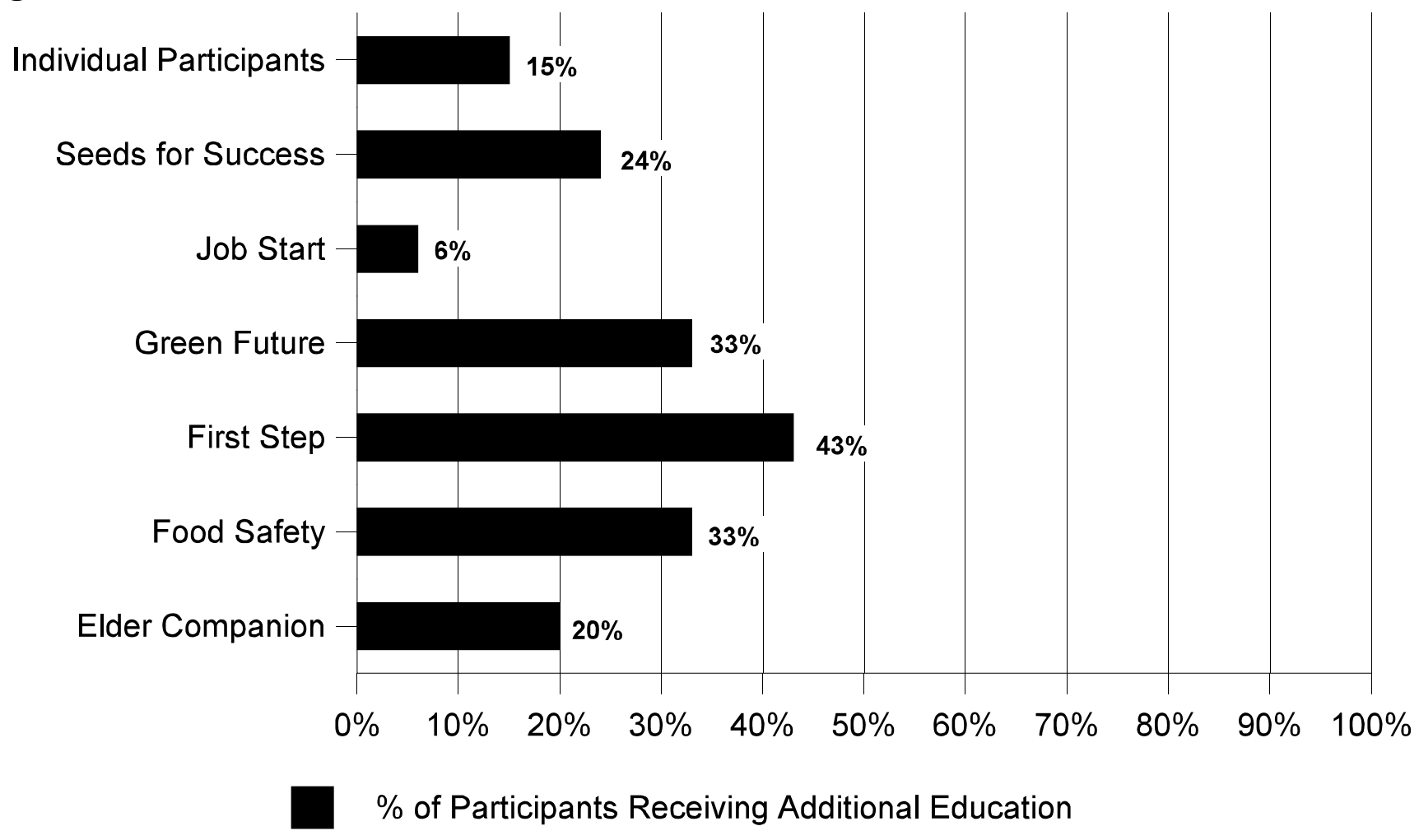

Figure 8. Percent of participants receiving additional education shown in Figure 8 indicates that First Step FastTrac $^{\mathrm{TM}}$ participants are more likely to get involved in additional education. However, the number of First Step FastTrac $^{\mathrm{TM}}$ participants is small and as the participant pool increases, this may change.

This report, Putting Knowledge to Work: Outcome Performance of the UF/IFAS Welfare-to-Work Initiative as of May 11, 2001, is part of the UF/IFAS Welfare to Work Initiative (Grant \#A6218) funded by the Florida Agency for Workforce Innovation (formerly Florida Department of Labor and Employment Security). The Principal Investigator is Elizabeth B. Bolton, Professor of Community Development, Department of Family, Youth and Community Sciences. 